Discussion Papers in

Economics and Econometrics

2000

This paper is available on our website http://www/soton.ac.uk/ econweb/dp/dp00.html 


\title{
ENVIRONMENTAL REGULATION, MULTINATIONAL COMPANIES AND INTERNATIONAL COMPETITIVENESS
}

\author{
ALISTAIR ULPH \\ and \\ LAURA VALENTINI \\ (University of Southampton)
}

August 1999

Paper presented at conference on Internationalisation of the Economy, Environmental Problems and New Policy Options, Potsdam, October 15-17, 1998.

We are grateful to Joaquim Oliveira Martins and other participants at the conference for helpful comments. Forthcoming in A. Ulph and P. Welfens (eds), Internationalisation of the Economy, Environmental Problems and International Competitiveness, Springer, Heidelberg. 


\title{
ENVIRONMENTAL REGULATION, MULTINATIONAL COMPANIES AND INTERNATIONAL COMPETITIVENESS
}

\begin{abstract}
Concerns have been expressed that in a global market place with mobile capital, national governments will have incentives to set weak environmental policies ("environmental dumping") to protect the international competitiveness of their domestic firms, that these incentives are particularly strong in industries where plants may be relatively footloose, so that governments are concerned to prevent "capital flight", and that footloose plants are particularly associated with multinational firms. It is then often suggested that appropriate policy responses would be to seek to harmonise environmental regulations or impose minimum standards for environmental regulations.

In this paper we set out these concerns in terms of a number of more precisely made claims and then review recent developments in economic analysis (including some of our own work) and empirical evidence to show that the claims cannot be generally sustained and that the suggested policies may be harmful. However, devising more appropriate policies is by no means straightforward.
\end{abstract}

Keywords: Plant location, Environmental Policy, Eco-Dumping, Competition

JEL Classification: F1, H4, L5, Q2

Mailing Address: Laura Valentini, Department of Economics, University of Southampton, Southampton SO17 1BJ. Tel: +44 1703595055 Fax: +44 1703 593858

e-mail:1.valentini1@ soton.ac.uk 


\section{INTRODUCTION}

There is considerable public concern that globalisation - the liberalisation of trade and capital flows - leads to policy competition between governments, which in the context of environmental policy may induce governments to set too lax environmental policies (environmental dumping) in order to protect their international competitiveness. It is further argued that this incentive is particularly strong when firms are footloose so that governments may worry about 'capital flight', and multinational firms are particularly prone to such footloose behaviour. The fear of environmentalists is that competition between governments to retain or attract such footloose firms is thought to trigger a 'race-to-the-bottom' in environmental policies. In the NAFTA debate the possibility of firms/plants relocating from the US to Mexico was an issue and a similar concern is expressed about the enlargement of the EU to include Eastern European countries. To counteract such incentives for environmental dumping it is often suggested that agencies such as the European Union should seek to harmonise environmental policies of member states or at least set 'minimum standards' for environmental policies.

Behind this set of concerns we can identify a number of separate claims:

Claim 1. Firms will locate production in countries with weaker environmental policies.

Claim 2. Countries with footloose firms will do less well than countries with less footloose firms.

Claim 3. Trade liberalisation gives governments incentives to weaken their environmental policies for strategic trade reasons ('environmental dumping').

Claim 4. There will be more environmental dumping when firms are footloose than when their locations are fixed.

Claim 5. Multinational firms are particularly prone to switch production between countries in response to environmental policies, in the extreme case closing plants in some countries.

Claim 6. The appropriate policy responses to environmental dumping are the harmonisation of environmental policies or the setting of 'minimum standards' for environmental policies.

In this paper we shall review recent literature, both in economic analysis and empirical work, and show that none of the above claims can be sustained as general propositions. In the next section we review what can be said in terms of economic analysis about claims 1 - 5 while in section 3 we review recent literature on empirical aspects of these claims. In section 4 we discuss the policy implications of the previous two sections, and in particular assess the status of claim 6 . 


\section{WHAT DOES ECONOMIC ANALYSIS TELL US ABOUT CLAIMS 1 - 5 ?}

To address all the issues addressed in claims 1 - 5 would require a model with three key features:

(i) To take seriously issues of location of plants and firms, and in particular of multinational companies requires models in which there are significant increasing returns to scale, captured most simply by fixed costs of setting up plants and firms This immediately implies that we will dealing with imperfectly competitive markets It also means that we shall need to consider strategic interactions between firms both in output markets and in their location decisions ${ }^{\text {. }}$

(ii) To take seriously the notion of 'environmental dumping' we also need to assume that there is strategic competition between governments in terms of their environmental policies and one definition of environmental dumping is to contrast the policies governments would set if they act non-cooperatively with those they would set if they acted cooperatively ${ }^{\text {B }}$. So we shall need to model a policy game between governments.

(iii) To take seriously the notion that in setting their environmental policies governments are concerned with their impact on location decisions of firms we need to assume not only that firms will change their location decisions depending on the environmental policies set by governments but that governments can commit themselves to environmental policies prior to firms choosing where to locate. Taken together with points (i) and (ii) this implies that we need to consider multi-stage games and that there will be important timing issues in such games. We shall follow the literature in contrasting two extreme cases. In Location Games governments are able to commit themselves to environmental policies prior to firms choosing their locations. We shall contrast this with what we call Market Share Games where firms first choose their locations and governments then set their environmental policies, and this contrast will throw light on issue of whether there is more or less environmental dumping when governments worry about capital flight ${ }^{4}$. This is a very crude contrast between the relative degrees of commitment of governments to their environmental policies and firms to their location choices ${ }^{5}$.

\footnotetext{
${ }^{1}$ For a review of what can be said about incentives for environmental dumping in competitive markets see Ulph (1997a).

${ }^{2}$ Modelling location choices can become complex because of the discrete nature of these choices. This causes payoff functions for firms to be discontinuous, and in turn this causes the welfare functions for governments to be discontinuous (see Markusen, Morey and Olewiler (1993), Ulph and Valentini (1997)) for further discussion.

${ }^{3}$ An alternative definition is to contrast the policies governments set when acting non-cooperatively with a simple 'first-best' rule for environmental policy such as equating marginal abatement and damage costs.

${ }^{4}$ Note that even in the Market Share Game firms may still base their location decisions on the environmental policies which they expect (rationally) governments to introduce after they have located.

${ }^{5}$ Of course a richer model would be a multi-stage game where one models explicitly what leads to different degrees of commitment by firms and governments; Feenstra (1998) conducts such analysis for the case where firms have to choose investment in capital, and shows that a multi-stage game can
} 
Not surprisingly, there is no single model which captures all the features set out above so we shall review a small number of models which cast light on different aspects of the claims we wish to test. We begin with an extremely simple model of location choice based which we used in a recent paper (Ulph and Valentini (1998)) and which draws heavily on the model by Hoel (1997). This has the merit of providing a setting in which many of the concerns and claims set out in the introduction can be justified. We shall then show how moving away from the very simple model invalidates the claims.

\subsection{The Simplest Possible Model.}

Assume that there is only one firm and only two countries in which it can locate. There are no transport costs or capacity constraints, so that the firm will only use one plant, so that the notion of a multinational firm cannot arise. The firm sells its product in countries other than the two in which it can locate. Production costs are the same in both countries. Production causes pollution, some of which may be abated at a cost. Unabated pollution causes damage in the country in which the firm is located, but countries have the same damage costs. Clearly the firm will locate in the country that sets the weaker environmental policy. We assume that the country in which the firm locates imposes a $100 \%$ pure profits tax so that profits accrue to the country of production. Governments use a simple emission limit $(e)$ to regulate pollution. Welfare of the country where the firm locates is thus given by profits of the firm less environmental damage, shown as $V(e)$ in Figure 1, while welfare of the other country is zero.

If the firm chooses its location before the government sets its policy, then the government in which the firm locates will simply set the emission limit, $e^{*}$, which maximises welfare. This will be the usual first-best emission limit such that marginal abatement cost equals marginal damage cost, so there is no strategic element to environmental policy. Since the policy is the same for both countries, the firm will randomise where it locates, so each country will get expected welfare $U\left(e^{*}\right)=$ $0.5 \mathrm{~V}\left(e^{*}\right)$. If governments choose their policies first, then if governments set the same emission limit, $e$, we assume that the firm randomises where it locates so that each government gets expected welfare $U(e)=0.5 \mathrm{~V}(e)$, shown in Figure 1. If governments set different emission limits the firm locates in the country with the higher limit, and that country gets welfare $V(e)$. The equilibrium of the game in emission limits will be a simple 'race-to-the-bottom' in which both governments set emission limit $\bar{e}$ where welfare gets driven to zero. It cannot be an equilibrium for the governments to set the

lead to different conclusions from a two-stage game but does not consider location decisions. D. Ulph (1995) also notes that rather than starting from the assumption that firms choose locations de novo in a world of liberalised trade and capital flows it may make more sense to assume that globalisation is a process so that one starts from a position of autarky in which there are already established firms located in different countries.

${ }^{6}$ For other surveys see Markusen (1996), Rauscher (1995), Wilson (1996).

7 This depends crucially on the assumptions that there are no consumers in each country and the country in which the firm locates earns all the profits. So although the firm is a monopolist the government is quite content for it to maximise profits. The only distortion as far as the government in which the firm locates is concerned is the environmental distortion. If there were consumers in the country the government would set policy weaker than first-best to offset the monopoly distortion; if the country did not capture all profits the government would set policy tougher than first-best as a way of capturing foreign profits. 
same emission limit below $\bar{e}$ because by setting a marginally higher emission limit a government could get welfare $V(e)>U(e)$, and it cannot be an equilibrium for governments to set different emission limits if the government with the higher emission limit gets strictly positive welfare, since the other government could set a marginally higher emission limit and get positive rather than zero welfare.

This very simple model would seem to confirm most of the fears outlined in the introduction: firms choose to locate where environmental policies are weakest (claim 1); competition between governments to attract capital induces them to weaken their environmental policies (claim 3) and indeed this takes the form of a 'race-to-thebottom'; environmental policies are weaker when governments have to worry about the location of firms than when they do not, i.e. $\bar{e}>e^{*}$ (claim 4$)$; and the countries are worse off with footloose firms than when firms are not footloose, in the sense that $U\left(e^{*}\right)>U(\bar{e})=0$ (claim 2). The model does not allow us to address claim 5.

However, even within the context of this very simple model, not all these claims are robust. For the argument depends on the assumption that $V\left(e^{*}\right) \geq 0$, so that there are some emission limits for which damage costs are less than the profits which the firm earns. But suppose environmental damage costs are so high that $V\left(e^{*}\right)<0$, then while the outcome with fixed location will be as before (the government in the country with the firm sets emission limit $e^{*}$ ) with endogenous location both governments will set such tough environmental policies that no firm would want to locate in their countries - the NIMBY outcome. This would immediately overturn claims 2, 3 and 4.

It might be argued that the NIMBY case is only relevant for a few extreme cases (e.g. disposal of nuclear waste) so that the general conclusion from this simple model is to confirm many of the concerns and claims outlined in the Introduction. We now turn to various ways in which the simple model might be extended.

\subsection{Allowing for Multi-National Production.}

A key feature of the simple model is that there are no transport (trade) costs so that, even if we take the more general Hoel (1997) version of the model which allows for consumers in both countries, the firm would only operate one plant. Markusen, Morey and Olewiler (1995) (henceforth MMO) use a model which has ayery similar structure to the simple Hoel model except that they have transport costs ${ }^{\text {, }}$, so that the firm has to decide whether to have a single plant, and if so where to locate it, or to have a plant in each country (i.e. to go multi-national). Note that an immediate implication is that if, in the absence of any environmental policies in either country, the equilibrium choice is for the firm to locate plants in each country, because profits are strictly greater with the multi-national equilibrium than with an equilibrium with a single plant exporting to the other country, then if one country introduces an environmental policy there will be a range of values for the environmental policy

\footnotetext{
${ }^{8}$ There are some other differences which do not affect the general point we make; thus there is no third set of countries to which the firm can export; where the firm sets up a single plant in one country the governments can use an export tax. Because, as noted in footnote 2, of the discontinuities this introduces in the firm's payoffs and hence welfare payoffs they have to rely on special functional forms and some numerical examples to illustrate their argument.
} 
before it would pay the firm to switch to the equilibrium with a plant located in the country with no environmental policy. Thus the introduction of transport costs, which is needed to rationalise a multinational pattern of production, provides a degree of protection to a country to set a tougher environmental policy than other countries without fear of losing plants to rival countries. So this contradicts claims 1 and 5.

MMO again compare the policies governments would set after the firm has made its choice of plant location, with the policies governments would set prior to the firm deciding where to locate its plant(s). MMO reach the same conclusion as Hoel about the possibility of a NIMBY outcome - with high enough damage costs both governments will set prohibitive environmental policies to deter any plant being located in their countries, despite the fact in terms of global welfare it would be desirable that the product be produced. But there is an interesting twist to the 'raceto-the-bottom' case. When governments set their policies after the firm has chosen its plant locations (so, as in the simple model, there is no strategic competition between governments) there will be two possibilities - the firm chooses a single plant and exports to the other country or it locates a plant in each country, with the first outcome being chosen when the fixed cost of setting up a plant is relatively high. In both cases when we switch to having the governments set environmental policies before the firm chooses plant locations then there will be competition to weaken environmental policies, so claims 3 and 4 remain true. But if in the non-strategic case, the outcome involved the firm setting up a single plant, then in the process of competition the firm may decide to switch to having two plants, while if the nonstrategic outcome involved the firm having two plants this will remain the outcome when the governments compete strategically. Thus strategic competition may lead to the firm proliferating plants, but, except in the NIMBY outcome, not to it reducing the number of plants. The rationale is this. The firm is trading off the fixed costs of setting up plants against the transport costs of having to export. Suppose in the nonstrategic case governments set tough environmental standards so that production costs are high; then output will be relatively low, transport costs will be low relative to total production costs and it will not be economic for the firm to carry two sets of fixed plant costs; however as the governments compete and weaken environmental policies this will reduce production costs relative to transport costs, expand sales in each country and make it more attractive for the firm to set up a second plant.

Thus allowing for the possibility of multi-national production means that, if again we exclude the NIMBY outcomes, in addition to governments setting weaker environmental policies when they take account of plant location decisions, this may lead to excessive numbers of plants being set up - too many multi-national plants. In other words the link between weak environmental policies and multinational firms may be the opposite of what environmentalists suppose - it is because governments set weak environmental policies that this may allow multinational patterns of production to come into being; multinational firms are a response to weak environmental policies rather than weak environmental policies being a response to multinational firms.

\section{$\underline{\text { 2.3 Allowing for Many Firms. }}$}


In 2.2 we extended the simple model by allowing a single firm to set up more than one plant. In this section we consider what happens if we revert to the assumption of no transport costs, so each firm has a single plant, but now assume there may be more than one firm. As the simplest possible extension to the simple model of section 2.1 we take the model of Ulph and Valentini (1998) in which there are two firms which engage in Cournot competition. The key difference this makes to the conclusions of the simple model is that even if we ignore the NIMBY case, environmental policy when governments set policy before firms choose to locate may be tougher than when they set policy after firms choose where to locate; i.e. claim 4 may no longer hold. There are four reasons why introducing more firms changes the conclusions of the simple model.

(i) With fixed locations there is now the possibility that the two firms locate in separate countries. In this case, given the assumptions we have made and contrary to the previous two sub-sections, there will be strategic incentives for governments to engage in environmental dumping and set weaker environmental policies than they would set if they cooperated ${ }^{9}$ for the usual rent-shifting reasons familiar from strategic trade theory. To see why this might change the conclusion it is possible that, for some parameter values, the non-cooperative equilibrium between governments when firms have already decided to locate in separate countries, involves such intense competition that governments set such lax environmental policies that countries get negative welfare. When governments set their policies before firms locate they would never choose to end up with negative welfare; so, for these parameter values, even if there was a race-to-the-bottom in which countries got zero wlefare with endogenous locations this may involve governments setting tougher policies than in the game where firms' locations are fixed.

(ii) Precisely because there is now competition between the firms, it may no longer be the case that relaxing environmental policies always leads to higher profits for firms; in the absence of environmental policies total output would be higher than that which maximises profits, so there will be cases (with low environmental damage costs) where toughening environmental policies may raise profits and this may limit the race-to-the-bottom.

(iii) If damage costs are strictly convex, then, for any given level of output and pollution by each firm, while having both firms locate in one country will double the profits that country can earn it will more than double the environmental damage costs that country has to bear. Now if we think of the two-firms analogue of the race-to-the bottom argument set out in Figure 1, we want to compare the welfare a country gets if it sets a higher emission limit than its rival and hence attracts both firms, $V(e)$, with the expected welfare it gets if it sets the same emission limit as its rival and both firms randomise where to locate, $U(e)$; in calculating this expected welfare we now include the possibility that the two firms locate in different countries. Because of the convex damage cost argument it may no longer be the case that $V(e)>U(e)$; indeed Ulph and Valentini show that there must always be some values of $e$ below $\bar{e}$ for which $V(e)<U(e)$ and indeed this may be true for all $e$. This introduces the possibility of multiple equilibria for the game where firms are footloose, and while

\footnotetext{
${ }^{9}$ In particular the assumptions of Cournot competition and the fact all profits accrue to the country in which the firm is located lead to environmental dumping (see Ulph (1997a) for more discussion.
} 
these will include the race-to-the-bottom equilibrium they may also include equilibria which have tougher emission limits than when firm locations are fixed. Hoel (1997) makes a similar argument when extending his model from one to many firms.

(iv) A further implication of the convex damage cost argument is that when we consider the environmental policies governments will set when firms' locations are fixed, it is quite natural to assume that they will set different environmental policies depending on whether one or two firms locate in their countries, in other words we can think of environmental policies being conditioned on the number of firms that locate in those countries. However the argument sketched out in (iii), and which is used by other authors when considering models of endogenous firm location with more than one firm ${ }^{10}$, assumes that governments set a single environmental policy independent of the number of firms, so that if governments set different emission limits then all firms locate in the same country. But if we want to compare the difference in policies when firms have fixed or endogenous locations, and we do this by varying the move structure of the game, then if we allow a government to condition its policy instrument on the number of firms located in its country under one move structure we should do so under both. This means that when governments set policies before firms locate, governments can separate the emission limits they set to attract one firm to locate from that which they set to attract both firms to locate. Speaking loosely this means that governments are not driven into an all-or-nothing race-to-the-bottom but can settle for sharing the firms between them. Perhaps not surprisingly, if governments know they can secure an equilibrium where one firm will locate in each country they will the same level of emission limits as if these locations were fixed, so we get exactly the same outcome irrespective of whether firms locations are fixed or endogenous. This occurs for a wide class of parameter values. This is illustrated in Figure 2 where $W(e)$ is the welfare a country gets when the two firms locate in separate countries and $V(e)$ is the welfare a country gets when both firms locate in a single country. $e^{N}$ is the Nash equilibrium emission limits the governments would set in the Market Share Game where they set policies after the firms have chosen to locate in separate countries. If the configuration of $W$ and $V$ is as shown in Figure 2, which is true for a wide range of parameters, then $e^{N}$ would also be an equilibrium of the Location Game where governments set policies before firms choose their location, because it would not pay a government to try to attract both firms to locate in its country.

In summary, introducing many firms means that even excluding the NIMBY outcome, it need no longer be the case that governments engage in more environmental dumping when firms choose their locations in response to government policies than when government policies are set after firms have fixed their locations, and indeed for a wide class of cases the move structure makes no difference. Ulph and Valentini (1998) showed that the greater the degree of substitution between firms' products (and hence the greater the degree of market competition) the more likely it was that environmental policy would be tougher in Location Games (endogenous locations) than in Market Share Games (fixed locations).

\subsection{Many firms and plants.}

\footnotetext{
${ }^{10}$ See Hoel (1997), Markusen, Morey and Olewiler (1993) although in the latter case the authors do not study policy competition between governments.
} 
Markusen (1996) extends the analysis of the two previous sections by considering a general equilibrium model with two identical countries (denoted $h$ and $f$ for home and foreign) and two sectors - a competitive sector and a non-competitive sector. Within the non-competitive sector firms may be national (i.e. a single plant in $h$ or a single plant in $f$ ) or multi-national (type $m$ ). The number of each type of firm and the amount that each firm produces is determined endogenously, using a zero-profit condition. Given the complexity of the model, Markusen does not analyse the noncooperative setting of environmental policies by the two governments but rather just studies the impact of the foreign government unilaterally introducing an environmental policy which can affect either the marginal or fixed cost of production in country $f$. However there are results from his model which allow us to say something about claim 5 - that multinational firms encourage the switching of production between countries in response to environmental policies.

Figure 3 shows the types of configurations of firms that exist in equilibrium for different combinations of trade costs and environmental cost penalties in country $f$. The top row shows what would happen in the absence of any environmental policy in $f$; for low transport costs only national firms exist, while for high transport costs only multinational firms exist. For low transport costs, as production costs rise in country $f$ rise, production will be switched away from $f$ firms to $h$ firms and eventually only $h$ firms survive. With high transport costs, as costs in country $f$ rise multinational firms will also switch production between from their $f$ to $h$ plants, and as costs in $f$ rise it is possible for national firms in $h$ to enter the market and export to $f$. Because of general equilibrium effects, type $f$ firms can also emerge. With high enough production costs, multinational firms shut down (this is just the converse of the argument in section 2.2 that saw multinational activity expand as environmental polices weakened) and eventually only $h$ firms survive.

Note first that the cost differential at which production in $f$ shuts down completely is (slightly) higher when we start with multinational production than when we start with solely national firms. Markusen also reports that a detailed analysis of production shows that production switches more slowly from $f$ to $h$ when we start with multinational firms than with only national firms. Both these findings would seem to contradict claim 5 - that multinational firms exacerbate the process of switching production out of countries with high environmental costs. However Markusen noted that these findings are not due to multinational firms per se but rather to the fact that the existence of multinational firms can only be rationalised when there are high transport costs and it is this that protects production in country $f$ from increases in its production costs due to environmental policy. However, in welfare terms high transport costs raise the costs of tougher environmental policies in $f$ for the obvious reason that it increases the cost to consumers in $f$ having to buy more of their consumption from country $h$ and this effect outweighs any production gains, at least for Markusen's model. Dampening down the loss of production in response to environmental policies may not be beneficial.

A similar point was made in Ulph (1994) where it was shown that using tax rebates to reduce the incentive for firms to relocate abroad in response to environmental policy (i.e. reducing the extent to which domestic firms are footloose) may be counterproductive if that leaves domestic firms faced with higher costs and hence 
domestic consumers with higher prices than would otherwise be the case; Motta and Thisse (1994) make a similar point with respect to the use of protectionist policies to reduce the incentives for firms to relocate abroad.

\subsection{Agglomeration Effects.}

In all the models studied in the previous sections, environmental policy has affected location decisions through its impact on costs of production and hence on profits. To focus attention on the impact of environmental policies on location we have assumed that countries are identical (so there are no comparative advantage factors affecting location decisions). In the models in sections 2.1 and 2.3 with no transport costs small differences in environmental policies would be sufficient to induce firms to locate in the country with weaker environmental policies. In the models in sections 2.2 and 2.4 transport costs, which are necessary to rationalise multinational production, provided a degree of protection for a country to set a tougher environmental policy than rivals without losing all its production. Indeed Figure 3 shows that as environmental costs rise in country $f$ there will be a steady decline in the number of plants and firms located in country $f$ rather than any sudden exodus of production. The reason for this is that if a small toughening of environmental policy in $f$ makes it marginally profitable for a plant to switch from country $f$ to country $h$ then that switch will marginally raise the profitability of firms that remain in $f$ and reduce the profitability of plants located in $h$, thus reducing the incentive for any other plant to switch location.

Consider what happens to this argument if what matters in making location decisions is more than just costs of production, but also proximity to markets or sources of supply. Thus suppose that because of the input-output structure of production for producers in a particular sector, a significant fraction of their market will be producers in other sectors who use the output of this particular sector as inputs to their production processes; similarly, a significant fraction of the inputs used by producers in the particular sector will be the outputs of producers in yet other sectors. Thus because sectors are linked in the structure of production, the location decisions of producers in different sectors become interdependent. This provides incentives for agglomeration of producers. Consider then what happens if a producer in a particular sector decides to close a plant in a particular location. As noted above, within the sector itself that has the usual effect that by reducing supply in that sector it will raise the profits of the producers who remain in that sector in that location. But it will also have two knock-on effects. It will reduce the demand for the products it used as inputs, and so reduce the profits of plants which supplied that producer, which will typically be plants located close to the original producer. Second it will raise the input costs of plants which used the output of the original plant as inputs, since they will now have to get their inputs from more distantly related producers. Again these customers will have been located close to the original plant. If these reductions in profits in related sectors were sufficiently strong to cause the closure of some of the plants in those sectors that would in turn have negative impacts on the profits of the plants remaining in the original sector, which, if inter-sectoral linkages were strong enough could offset the original boost to profits of those plants caused by the closure of the original plant. Venables (1994) and Ulph and Valentini (1997) analyse models of strategic environmental policy when there are agglomeration effects due to intersectoral linkages of production. 
There are two implications of this analysis of agglomeration. First, there is the possibility that with strong inter-sectoral linkages there is the scope for quite catastrophic effects of policy on location decisions of producers when critical thresholds are reached. This can be characterised by the concept that a country can lose its manufacturing base in a particular set of related industries. Thus even if there are transport costs which would be expected to give countries a degree of isolation of their production from increases in domestic costs, agglomeration effects may reintroduce the possibility that there could be critical thresholds at which a small toughening of environmental policy in one country triggers a substantial exodus of production. Second, when agglomeration effects are strong what matters to producers is being located close to producers in related sectors; where that happens to be is less important. This can mean that for a range of parameter values, including policy parameters, there can be multiple possible equilibria, e.g. it is perfectly consistent with a particular set of parameters that a particular set of industries be located either in $h$ or $f$, while outside that range of parameters there may be a single equilibrium. This has an important implication for policy that it introduces a kind of "hysteresis effect". Suppose that at a very low level of environmental taxes, say, the only equilibrium is for a set of industries to locate in $f$. As environmental policy in $f$ gets stricter there may emerge another equilibrium in which the industries could locate in the $h$. But given that the industries are already located in $f$, no individual producer would wish to switch to $h$. When environmental policy in $f$ gets strict enough, it is no longer possible to sustain the industries in $f$, and production switches to $h$. But now if $f$ subsequently relaxes its environmental policy, by the same argument, the producers will not switch back to $f$ unless the environmental policies reverted to the very low level at which location in $f$ was the only possible equilibrium. Figure 4, from Ulph and Valentini (1997) illustrates this possibility for a two-country, two-sector (upstream and downstream) model in which there are two firms in each sector who have to decide how many plants to locate in each country. For a wide class of parameter values, in the absence of any environmental policy agglomeration effects lead to all firms locating a single plant in country 1. Country 1 introduces an emission tax but as long as it lies below 1.5 the strength of agglomeration effects means that it remains a unique equilibrium for all firms to locate in country 1. For taxes between 1.5 and 2.0 there is a second equilibrium in which 3 firms relocate in country 2 ; for taxes above 2.0 this second equilibrium is unique. So an emission tax above 2.0 would trigger a rapid exodus of firms from country 1 but country 1 would have to cut its tax below 1.5 to attract these firms back again.

\subsection{Time Structure Revisited.}

As D. Ulph (1995) notes, it is not really appropriate to use the term "hysteresis" for the above discussion, for there is no real dynamics in which environmental policies change and firms relocate; it is simply a question of multiple equilibria in what we have called a Location Game with agglomeration effects where we start with essentially a blank sheet in terms of firms and their locations and consider how firms would choose the locations of their plants once and for all in response to environmental policies previously set by governments. As noted in footnote 5, a 
proper analysis of hysteresis would require a multi-period interaction between governments and firms in which governments can change their policies from one period to the next and firms can change their locations in response to these changes in policy. As he notes, it is then important to distinguish between sunk costs, which are incurred when a plant is initially established and would have to be incurred again if a plant was relocated, from recurrent fixed costs of producing a positive output level in any period. It is the need to incur this sunk cost which gives a degree of commitment to firms location decisions and which may mean that locations selected in previous periods may not be changed in response to policies which would have induced an alternative location choice by firms making that location choice from scratch $^{111}$. For such a multi-period model of hysteresis to work one would also need to explain why governments would wish to change environmental policies from one period to the next, and whether there are any factors (analogous to sunk costs) which might lead governments to commit to environmental policies (reputation effects might be a candidate). In his paper, the dynamics used by D. Ulph to motivate a change in environmental policy is the opening up of countries to trade. This has the usual effects - an increased market size effect which acts to increase profits, and increased competition effect which acts to reduce profits and a relocation effect of production switching from countries with high autarkic costs to those with low autarkic costs. In addition there will be any induced change in government environmental policies. He shows that while the opening up of trade will lead governments to set weaker environmental policies than under autarky, for a wide range of parameters the number of firms will be exactly the same as under autarky. This is because the gain in profits due to the net effect of increased market size and weaker environmental policies less the impact of increased competition is insufficient to compensate for the sunk costs needed to establish new firms.

However it should be noted that the trade liberalisation which drives the change in environmental policy is unanticipated by firms, for otherwise this would have influenced their initial location decisions. In the context of environmental policy we know of no fully specified multi-period analysis in which governments calculate their environmental policies each period and firms calculate their location decisions each period, with firms and governments acting strategically and with rational expectations, with a proper account of what might determine the relative degrees of commitment by firms and governments which would allow a proper analysis of hysteresis effects.

\subsection{Summary.}

If, in addition to the complexities outlined in the previous paragraph, we add the desirability of including transport costs and the simultaneous determination of multinational and national firms, and the possibility of inter-sectoral linkages with agglomeration effects it is clear why we said at the start of this section that we are a long way from having a single model which can address all of the issues outlined in the Introduction. Nevertheless from our review of a number of models which throw

\footnotetext{
${ }^{11}$ Motta and Thisse (1994) also note that because firms have prior locations in which they have incurred sunk costs the extent of delocation in response to environmental policies may be less than suggested by models which ignore such sunk costs
} 
some light on certain aspects of the issues we can reach the following conclusions about claims $1-5$ set out in the Introduction.

1. Allowing for transport costs, agglomeration effects, sunk costs all mean that even with no comparative advantage effects there could be significant differences in environmental policies between countries without inducing firms to switch plants to countries with weaker environmental policies.

2. Even if firms are tempted to relocate abroad in response to difference in environmental policies it does not follow that a country is better off having less footloose firms, because if that leaves domestic firms with higher costs and domestic producers with higher prices, welfare may be lower than if firms had relocated abroad and exported back to the home country.

3. While there are certainly circumstances under which governments have incentives to weaken environmental policies when acting non-cooperatively, as we have shown there are other cases where governments will want to set too tough policies (e.g. NIMBYISM, where governments seek implicitly to tax foreign profits).

4. While there are models where governments will set much weaker environmental policies when they are trying to influence locations than when they set policies with fixed locations, this is by no means always the case; the discussion in section 2.3 showed that there may be many cases where environmental policies are unaffected by the timing of government policy setting relative to firms location decisions; when policies differ, the more intense is market competition (as measured by the degree of substitution between firms products) the more likely it is that environmental policy will be tougher when governments take account of the location decisions of firms in setting their policies.

5. Finally the discussion in sections 2.2 and 2.4 emphasised that because multinational patterns of production are most likely to be competitive against national production when transport costs are high relative to production costs, these high transport costs will also reduce the sensitivity of domestic production to differences between domestic environmental costs and foreign environmental costs. Moreover it may be that multinational firms are a response to weak environmental policies rather than weak environmental policies being a response to multinational firms. 


\section{EMPIRICAL STUDIES.}

In this section we review some of the empirical literature which attempts to assess whether environmental legislation has a significant impact on the plant location decisions of firms. Because there are several excellent recent surveys of this literature, (Cropper and Oates (1992), Markusen (1996), Rauscher (1995) and especially Levinson (1996a)) we shall be relatively brief. We shall draw heavily on the survey by Levinson (1996a). He begins by quoting a number of sources from international organisations such as OECD, international and national industrial associations, US politicians of all parties who all believe that industrial delocation in response to stringent environmental legislation is a major issue and have proposed steps to try to limit its effect. However, he then surveys a wide range of different kinds of evidence which suggest that these concerns are not borne out in practice.

The first kind of evidence reviewed by Levinson (1996a) is surveys, from different countries, of factors which businesses say influence their international location decisions, and in the vast majority of cases environmental regulations are unimportant; there is some evidence that in particular industries, such as chemicals, environmental regulations feature more importantly (Knogden (1979) in a survey of West German firms that invested in developing countries), although these industries were also more sensitive to all cost factors. One possible explanation is an UNCTAD survey of multinational companies which suggested that such companies were concerned with environmental regulations in their home countries rather than their host countries - i.e. they applied the same (tougher) environmental regulations wherever they located.

The second form of evidence is data on trade patterns. Most of these studies use various aggregate indicators of trade to see whether they are influenced by environmental variables. For example, Grossman and Krueger (1993) studied USMexico trade patterns for a wide range of industries and showed, as Heckscher-Ohlin would suggest, that the US tends to import from Mexico goods that have relatively low skilled labour and capital content; they also included a variable capturing US pollution abatement costs by industry and showed this had a positive effect on imports from Mexico, but the variable was quantitatively small (and statistically insignificant) so that whatever effect US environmental legislation had in encouraging imports from Mexico was trivial. As Levinson (1996a) notes, a problem with almost all these studies is that they fail to properly control for all the other factors that might influence trade patterns. An exception is a study by Tobey (1990) of trade in 5 products which are pollution intensive; he regresses net exports of these 5 products for a range of countries against 11 factor-endowment variables (the other factors which might explain trade patterns) and a variable which measures the strictness of the countries' environmental policies on an index of 1 to 7 . The environmental strictness variable is never significant, but Levinson (1996a) comments that the other variables do not have sensible patterns either so it may be that the data is just not adequate to address the question.

The final set of studies surveyed by Levinson (1996a) are studies of location decisions by US firms across US states, which again consist of survey data and econometric studies of establishment-level decisions. Of the latter, the most 
comprehensive to date is one by Levinson himself (Levinson (1996b)) $)^{12}$ This is a study of the locations of new plants (those that appeared in the 1987 quinquennial Census of Manufactures but not the 1982). The use of new plants gets round the problem of sunk costs noted in the last section; another reason for focusing on new plants is that many environmental regulations apply specifically to new plants. A major difficulty with studies of this type is the construction of appropriate measures of environmental stringency and Levinson confronts this issues by using six different measures of stringency - three being various indicators of stringency of legislation, one being number of employees involved in state environmental agencies (to capture stringency of enforcement rather than just what is on the statute book) and two measuring abatement costs. The model follows a standard conditional logit model of plant location in which the probability of a plant in locating in a particular state is related to a whole set of state characteristics - business taxes, employment costs, energy costs, unionisation, infrastructure etc and the environmental stringency variable. Levinson first analysed the full sample of new firms and showed that the location decisions of new plants which were branch plants of large companies were more sensitive to 'manufacturing climate' than new plants in general, which would be consistent with the view that multinational firms are more sensitive to environmental legislation than other firms, and in the rest of his analysis he concentrates on the new branch plants opened by largest 500 multi-plant manufacturing firms. The results of the conditional logit analysis shows that while the environmental stringency variable is always negative, it is significant in only two cases an index of legislative stringency constructed by the Fund for Renewable Energy and the Environment and an index of abatement costs. However even where these variables were significant, an analysis of the effects of an increase in environmental stringency (by one standard deviation) shows that the quantitative impact would be small (the probability of a plant locating in a state would drop by $1.73 \%$ ). Levinson then studied the location decisions by individual industries (17 different SIC codes) and compared the impact of the environmental stringency variable with the overall pollution abatement costs to see if 'dirty' industries were more likely to be adversely affected by environmental legislation than clean industries and found no significant pattern.

Similar results can be found in analyses of location decisions in other countries; an interesting recent example is a World Bank study (Mani, Pargal and Huq (1997)) of location decisions in India since studies for developing countries have been rare. They apply the same methodology as Levinson to all new large (over Rs 500 million) industrial projects in India in 1994, choosing large projects on the presumption that they would be more footloose. Stringency of environmental regulation is captured by the number of prosecutions in a state under the Air and Water Acts normalised by the number of medium and large size plants in the state. They find that environmental stringency actually has a positive effect on location choices, although this is not significant. Restricting attention only to the five most polluting industries confirms the result.

The accumulation of evidence from many different kinds of studies and many different data sets all points to the same conclusion that environmental regulations

\footnotetext{
${ }^{12}$ For example the study by McConnell and Schwab (1990) considers only the motor vehicle industry.
} 
either have no significant deterrent effect on plant locations, and where there is such an effect it is quantitatively small. In either case there seems to be a discrepancy between the public perception that capital flight caused by environmental legislation is sufficiently serious to warrant policy action and the available evidence. Levinson (1996a, b) summarises the four explanations why the empirical evidence shows such small effects, and whether this suggests the studies have not addressed the real issue.

(i) He first dismisses the standard argument that environmental costs are too small to have an effect - in some industries in the US they can account for up to $15 \%$ of costs and this should be large enough to influence location decisions.

(ii) A second possibility is that the various studies do not properly control for the different degrees of 'footlooseness' across types of firms or industries. We noted that Levinson focused on branch plants of large companies and Mani Pargal and Huq concentrated on large projects in both cases because it was believed that these would be more footloose (Levinson had evidence to support this). But these may not really capture footlooseness. A recent study of trade data by van Beers and van den Bergh (1997) splits industries into resource-based and non-resource-based, with the later being presumed to be more footloose, and finds that there is a more significant effect of environmental regulation in footloose industries.

(iii) A third possibility, which relates to discussion of policy in the next section, is that there may be omitted political economy dimensions. Levinson (1996a) refers to his 'cynical interpretation' that it would pay industry and politicians to exaggerate the threat that environmental legislation poses to local employment to justify other forms of assistance given to industry. Frederikson (1997b) has a theoretical model which supports this view (i.e. in a political economy equilibrium tough environmental legislation is offset by other subsidies offered to industry); in a personal communication he says this is being confirmed by empirical modelling for US states. This suggests that studies may not be properly picking up all the state taxes and subsidies offered by state governments.

(iv) Finally there may be offsetting comparative advantage aspects which are not being properly picked up by the variables used to control for other factors affecting location decisions. Almost all of these other factors are cost related. A particular aspect of this argument would relate to agglomeration effects. Returning to the theoretical discussion in the last section, this could be a possible explanation the discrepancy between rhetoric and evidence; for the theory suggested that with strong agglomeration effects there could be a wide range of differences of environmental policies which would have no effect on location decisions, but then a critical threshold could be reached where a small further difference in policies has a 'catastrophic' effect; the empirical evidence is picking up the former effect while the policy concern is picking up the latter. It is obviously impossible to test this conjecture using conventional econometric modelling. To assess whether in practice inter-sectoral linkages are strong enough to provide this kind of catastrophic effect Venables (1994) used a calibrated model of the world chemical industry, which is one which is always identified as highly polluting and thought to be particularly vulnerable to environmental legislation. The industry is split into two sectors: basic chemicals and other chemicals; and there are four country groups: North America, 
Far East (Japan, Australia, New Zealand), Europe (EU+EFTA), and Rest of the World (other versions of the model have used different industrial sectors and intraEU countries). The linkage between the sectors is that basic chemicals contribute $25 \%$ and $17 \%$ of the gross costs of producing basic chemicals and other chemicals respectively, while the corresponding figures for other chemicals are $2 \%$ and $9 \%$. The policy instrument he uses is an energy tax imposed unilaterally by Europe (energy accounts directly for about $14 \%$ of the gross costs of basic chemicals and $3.5 \%$ of other chemicals). Table 1 shows the impacts of different levels of taxes on the number of plants $(\mathrm{N})$ and the unit operating costs of production $(\mathrm{C})$ in the two industries in the three main blocks.

Table 1 Impacts of a European Energy Tax on Plants and Costs (Index Form, No Tax Case 100)

\begin{tabular}{|c|c|c|c|c|c|c|c|c|c|c|c|c|}
\hline Tax & \multicolumn{9}{|c|}{ BASIC CHEMICALS } & \multicolumn{2}{l|}{ OTHER CHEMICALS } \\
\hline$\%$ & $\begin{array}{l}\text { North } \\
\text { America }\end{array}$ \\
\hline & $\mathrm{N}$ & $\mathrm{C}$ & $\mathrm{N}$ & $\mathrm{C}$ & $\mathrm{N}$ & $\mathrm{C}$ & $\mathrm{N}$ & $\mathrm{C}$ & $\mathrm{N}$ & $\mathrm{C}$ & $\mathrm{N}$ & $\mathrm{C}$ \\
\hline 10 & 106 & 100 & 101 & 100 & 83 & 102 & 101 & 100 & 100 & 100 & 94 & 101 \\
\hline 20 & 113 & 99 & 101 & 100 & 64 & 105 & 102 & 100 & 101 & 100 & 87 & 102 \\
\hline 30 & 122 & 99 & 102 & 100 & 44 & 107 & 103 & 99 & 101 & 100 & 81 & 104 \\
\hline 40 & 135 & 98 & 102 & 100 & 18 & 110 & 104 & 99 & 101 & 100 & 73 & 105 \\
\hline 50 & 145 & 98 & 103 & 100 & 0 & 112 & 105 & 98 & 102 & 100 & 67 & 106 \\
\hline
\end{tabular}

What this shows is that when the energy tax rate reaches $50 \%$, this will close down the European basic chemicals industry, with most of the production shifting to North America. Notice that given the moderate strength of the inter-sectoral linkages, there is no catastrophic decline in the industry at a particular threshold (nor was there any hysteresis effect), but the decline in plant numbers does accelerate as the tax rises. To understand the importance of the plant location decisions note that at the $50 \%$ tax rate unit costs have risen by $12 \%$ in Europe and declined by $2 \%$ in North America, so European competitiveness has declined by $14 \%$ relative to the U.S. Just under half of this can be accounted for by the effects of the energy tax on costs (both directly and indirectly through the higher costs of intermediate inputs). The rest of the cost increase is accounted for by the fact that suppliers are relocating to North America. Thus agglomeration effects have doubled the impact of the energy tax, which supports the claim that conventional models may understate the impact on competitiveness of environmental policies.

In summary, the evidence to date provides little support for the concerns expressed by environmentalists and policy makers about the threat of delocation posed by stringent environmental legislation. We suggest that more attention to properly capturing the footlooseness of industries, to recognising the political dimensions and hence ensuring that all forms of industry assistance are captured, and allowing for agglomeration effects may help to reconcile the difference between empirical evidence and political rhetoric, although we do not exclude the possibility that popular debate is just blind to proper evidence. 


\section{POLICY IMPLICATIONS.}

From the review of economic analysis in section 2 we concluded that if governments act non-cooperatively they may seek to manipulate their environmental policies for strategic trade reasons in markets which are imperfectly competitive, but this need not always take the form of setting too lax environmental policies, nor is it the case that concerns about footloose firms necessarily give stronger incentives for weakening environmental policies than for sectors where firms locations can be taken as fixed, nor is it the case that multinational firms exacerbate switches of production between countries. From the review of the empirical literature we concluded that there was no very strong empirical evidence that firms' location decisions were influenced by environmental policies. From this it might be concluded that policy concerns about delocation and environmental dumping are significantly exaggerated and so there is little need to do anything about it. This is reinforced by the argument that what lies behind the environmental dumping argument is essentially a 'missing instruments' problem. When markets are imperfectly competitive governments may have incentives to engage in strategic trade policies. If such policies are outlawed by trade liberalisation agreements then governments may turn to other policies, such as environmental policies, as proxies. But the same argument would apply to other policies, such as employment protection policies, and following the discussion of the empirical evidence, labour costs are in general more significant than environmental abatement costs and so environmental policy may not be the main focus of strategic behaviour.

For the purpose of this section however, let us suppose that strategic manipulation of environmental policies is an issue to be taken seriously and ask what should be done about it. We shall address this question in its most general context, without explicit reference to delocation or multinationals, since, as we have argued, if there are incentives for environmental dumping they are not confined to delocation and multinationals. Since the problem of strategic competition arises from governments setting their environmental policies non-cooperatively, the first issue is what institutions might induce international co-ordination of domestic environmental policies. Three possibilities might be considered. The first is to allow individual governments to take action against countries who they believe are engaging in environmental dumping, for example by reforming GATT articles to allow the use of countervailing tariffs against environmental dumping. There are many reasons to oppose this approach and we do not pursue it ${ }^{13}$. A second possibility is the use of International Environmental Agreements as proposed for transboundary pollution. However this raises a whole set of other issues we do not wish to explore here. So we will simply assume that there exists some supra-national agency which can be given the power to set national environmental policies, which for concreteness we shall refer to as the "federal government" with national governments being "state

\footnotetext{
13 These reasons include: it is government not firms that are "dumping"; the difficulty of one government establishing what should be the "right" environmental policies of another government against which to measure "dumping"; if governments are engaging in environmental dumping for strategic trade reasons or at the behest of industrial lobby groups, what reason is there to believe that the countervailing tariff will not be used for similar purposes? For further discussion see Rauscher (1997), Bhagwati (1996).
} 
governments", but recognising that this covers arrangements which are not formally federal, such as the EU.

The next question is what form of intervention the federal government might make in state governments' environmental policies. A commonly proposed approach is harmonisation of environmental policies supported by environmentalists toprevent a "race-to-the-bottom" and by industrialists to provide a "level playing field" 14 . For the purpose of this section we shall take a strict definition of harmonisation to mean imposing either the same environmental standards or the same equiproportionate tightening of environmental standards.

Harmonisation is neither necessary nor sufficient to ensure the absence of distortions to policy. It is not sufficient because if all countries were identical they would all impose the same environmental policy but that would still differ from either the firstbest or the cooperative level of policy. It is not necessary because if countries differ in marginal damage costs or marginal abatement costs then first-best or cooperative environmental policies should differ between countries. Indeed, if countries differ significantly, then harmonisation cannot achieve even a Pareto improvement over the non-cooperative outcome (see Kanbur, Keen and Wijnbergen (1995), Ulph (1997b)). This is illustrated in Fig. 5, based on Ulph (1997b) where, assuming just two states, we show the state governments' reaction functions $e_{1}=R^{1}\left(e_{2}\right), e_{2}=R^{2}\left(e_{1}\right)$ as well as their iso-welfare contours. The first key point to note is that we have two versions of this diagram depending on whether environmental policies are strategic substitutes (Fig. 5a) or strategic complements (Fig 5b); depending on the nature of the model being employed or the nature of the environmental policy instrument being used by governments, either of these is possible. The second point to note is that in both cases we have shown the outcome where there is "environmental dumping" - there is a set of policies in the shaded area which would make both countries better off than in the non-cooperative equilibrium (point $\mathrm{N}$ ), and these would involve both states having tougher (lower) emission standards than in the non-cooperative equilibrium. The third point to note is that we have assumed a significant asymmetry between the two states (e.g. different damage costs) so that in the non-cooperative equilibrium between state governments emission standards are laxer (higher) in state 1 than in state 2.

If harmonisation involves setting equal emission standards for both states, a point on the $45^{\circ}$ line, then as can be seen from the diagram any such point would make state 1 worse off than at point $\mathrm{N}$. The reason is obvious. Harmonisation involves two aspects. It attempts to reduce total emissions, and since the non-cooperative equilibrium involves total emissions which are too high in terms of the total welfare of the two countries such a move will in general make countries better off. But it also involves changing market shares, with the high emissions country losing market share to the low emission country. This harms the high emission country, and if countries are sufficiently different, this second effect outweighs the first. As shown in Ulph (1997b), countries would only have to differ by about 50\% in damage costs for

\footnotetext{
${ }^{14}$ Bhagwati (1996) critiques various arguments that have been proposed for harmonisation of environmental and labour policies, and Leebron (1996) discusses different senses in which policies might be harmonised.
} 
harmonisation not to yield a Pareto improvement over the non-cooperative equilibrium. If harmonisation involves either equal absolute or proportionate reductions in emission standards, then it is clear from Figure 5 that this form of harmonisation may improve on the non-cooperative equilibrium.

While it is obvious that with sufficient asymmetries between countries the strict form of harmonisation of environmental policies will not work, it is sometimes thought that a policy of minimum environmental standards would be desirable, on the grounds that it would raise environmental standards in countries which fell below the minimum standard, and if other countries choose to respond by also raising their standards it would only be because they were better off by doing so. The argument is that one "ratchets up" environmental standards across nation states. But this argument will also fail to deliver a Pareto improvement over the non-cooperative equilibrium if environmental policies are strategic substitutes as shown in Figure 5a. If state 1 is compelled to reduce its emission standard below the level $e_{1}^{N}$ but above $\tilde{e}_{1}$, state 2 would respond by raising its emission standard to a point on its reaction function between $\mathrm{N}$ and $\mathrm{M}$. This clearly makes the home country worse off. Any minimum standard tougher than (i.e. lower than) $\tilde{e}_{1}$ would be equivalent to strict harmonisation.

However Figure 5b shows that if environmental policies are strategic complements then the 'ratchet effect' works, and any combination of policies on state 2's reaction function between $\mathrm{N}$ and $\mathrm{M}$ would be a Pareto improvement on the non-cooperative outcome.

Thus neither of the policies frequently discussed - strict harmonisation or minimum standards - may yield improvements over the outcome where state governments are just left to set their own policies, thus contradicting claim 6 in the Introduction. Even if they do yield Pareto improvements over the non-cooperative equilibrium there is no reason in general to believe that they will be Pareto optimal for the two states. The obvious approach is for the federal government just to impose a cooperative solution. That raises the question the standard question when consideration is given to moving powers from state to federal level of whether the federal government would have enough information to calculate such an equilibrium. Ulph (1997b) assumes that damage costs are private information to state governments, so that any set of environmental policies imposed by the federal government would need to satisfy incentive compatibility constraints. The obvious constraint here is to prevent countries with high damage costs pretending to be low damage cost countries in order to be allowed to set lax environmental policies and hence obtain larger market shares. As Ulph (1997b) showed this can lead to environmental policies in countries which have different damage costs being more similar to each other than would be the case if the federal government had full information. The reason is simply that the need to satisfy the incentive compatibility constraint means that countries with high damage costs have to be rewarded for revealing that information by being allowed to produce more output, and pollution, than would be the case with full information. However this falls short of full harmonisation.

So far in this paper we have assumed that all governments are welfare maximising. But there is another reason why state governments may not implement first-best environmental policies and that is because they are responding to political influence 
exercised by powerful lobby groups. There is now a small literature applying political economy medels of electoral competition or political influence to trade and environment ${ }^{15}$. As with strategic trade arguments, these models can explain why, even in a small country, a government may not implement first-best environmental policies, or pursue free trade, but deviations from first-best could involve either too lax or too tough environmental policies depending on relative strengths of lobby groups. This literature also explains why environmentalists may support protectionist groups. However, this literature does not provide any support for a policy of harmonisation, for two reasons. First, even if it is true that environmental policies in some states are not first-best, that does not provide a reason to co-ordinate reforms of environmental policies; there have to be other reasons, such as those provided by strategic trade literature, for co-ordinating environmental policies. Second, the literature is entirely positive, and does not address the issue of whether or how to limit political influence on environmental policies.

Johal and Ulph (1998) address this latter question in a model which builds on work of Boyer and Laffont (1996) and extends the model of Ulph (1997b) to include political economy elements. Thus suppose that federal and state governments can be elected to be either Green or Industrial in the sense that a Green government uses a utility function which gives environmental damages a greater weight than in a true welfare function while an Industrial government uses a utility function which gives environmental damage too little weight. Pollution is entirely local, i.e. it affects only the state in which it occurs. There is a key asymmetry of information about damage costs. We shall continue to assume that it is only the state government which knows how damaging pollution is in its state. In particular this information is not available to either the federal government or the voters in the state. Thus, it is only when the state government comes into power that it learns a key parameter of its damage cost function (which determines the level of total and marginal damage cost for any given level of emissions). If environmental policy is to be set at the federal level then the federal government will have to provide incentives for state governments to reveal this information to the federal government. There are two prior constitutional choices that the people in the two states face: whether to delegate the setting of environmental policy to the states (in which case they will act non-cooperatively, so we get environmental dumping) or to the federal government; and whether or not to 'tie governments hands', i.e. to mandate the appropriate government (state or federal) to implement a specific environmental policy, that which maximises expected social welfare. We say expected social welfare because, as already noted, at the time the constitutional choice is made voters will not know the true value of environmental damages, and so if any policies are mandated at the constitutional stage they must be based on the expected value of environmental damages. Note that another key aspect is that at this prior constitutional stage the expected value of damage costs is the same for both states, so that any difference between states relates to the ex post damage costs, not the ex ante damage costs. Thus society essentially has a choice between allowing governments to come into power and learn the true value of environmental damages before setting environmental policies, but recognising that elected governments will pursue objectives which reflect the interests of the party in

\footnotetext{
${ }^{15}$ See Hillman and Ursprung (1992, 1994), Frederikson (1997a, 1997b), Rauscher (1997); Ulph (1998) provides an overview.
} 
power, not social welfare; or else mandating governments to pursue policies which maximise expected welfare, but based only on the expected value of damage costs not the actual value of damage costs. Note that in the latter case, because expected damage costs are the same in both countries, tying governments hands will mean that environmental policies will be harmonised. Johal and Ulph(1998) show that whether or not it is decided to tie governments hands, it is better to set environmental policy at the federal rather than state level, and that when policy is set at the federal level it is more likely that society will want to tie governments hands; this is essentially because when policy is set at the federal level the gain to having policy set by governments who know the true value of environmental damage costs is reduced by the asymmetry of information between state and federal governments. This might provide some explanation for why as trade has become liberalised and hence the need to co-ordinate domestic environmental policies has increased there have been increasing calls for harmonisation of environmental policies; the explanation provided here is that harmonisation is designed to limit the extent of political influence on federal policy making.

To summarise, in this section we have taken seriously the issue of non-cooperative nation state governments engaging in environmental dumping and asked what could be done to prevent this. We have presumed the existence of some supra-national body ('federal government') to whom powers can be given to implement policies to maximise the joint welfare of nation states. We have shown that widely canvassed policies such as harmonisation or minimum standards may not give Pareto improvements over the non-cooperative outcome depending on the degree of asymmetry between nation states and on whether environmental policies are strategic complements or strategic substitutes. In any case such policies are unlikely to be Pareto efficient, and we then investigated two possible limitations on the federal government implementing the cooperative solution - asymmetric information between state and federal governments, which does not justify policies such as harmonisation, and political influence, which, within a very special model, may provide some justification for harmonisation. However, if one is considering the possibility of restricting what governments do, then it may be more sensible to mandate state governments not to engage in strategic environmental policy in the first place (see Grossman and Maggi (1998) for related discussion in the context of strategic trade policy). 


\section{CONCLUSIONS}

In this paper we have addressed a number of concerns raised in recent debates on globalisation that faced with the threat of delocation of plants to countries with weaker environmental polcies, a threat that is particulaly associated in the public debate with multinational companies, nation states will be forced to engage in a raceto-the-bottom in terms of environmental policies. To counter this possibility it is often recommended that there should be harmonisation of environmental policies, or at least the imposition of a set of 'minimum standards' for environmental polcies.

We restated the above concerns in terms of six more specific claims. We reviewed some recent economic models and have shown that there is little substance to the fears about a race-to-the-bottom and that even if there were concerns about environmental dumping the usual policy prescriptions cannot be sustained in general. Our review of the empirical literature has also cast doubt on the significance attached in the debate to fears of delocation. 


\section{REFERENCES}

Bhagwati, J. (1996) "The Demands to Reduce Domestic Diversity among Trading Nations", in J. Bhagwati and R. Hudec (eds.) Chapter 1.

Bhagwati, J. and R. Hudec (1996) (eds.) Fair Trade and Harmonisation, MIT Press, Cambridge, Mass.

Boyer, M. and J-J. Laffont (1996) "Toward a Political Theory of Environmental Policy”, Nota do Lavoro 56.96, FEEM, Milan.

Cropper, M. and W. Oates (1992) "Environmental Economics: A Survey" Journal of Economic Literature, 30, 675 - 740.

Feenstra, T. (1998) Environmental Policy Instruments and International Rivalry - A Dynamic Analysis, Tilburg University.

Frederikson, P. (1997a) "The Political Economy of Pollution Taxes in a Small Open Economy", Journal of Environmental Economics and Management, 33, 4458 .

Frederikson, P. (1997b) “Why Don't Environmental Regulations Influence Trade Patterns?", mimeo, World Bank.

Grossman, G. and A. Krueger (1993) "Environmental Impacts of a North American Free Trade Agreement", in P. Garber (ed.) The Mexico-US Free Trade Agreement, MIT Press, Cambridge, Mass.

Grossman, G. and G. Maggi (1998) "Free Trade versus Strategic Trade: A Peek into Pandora's Box", CEPR Discussion Paper 1784, London.

Hillman, A. and H. Ursprung (1992) "The Influence of Environmental Concerns on the Political Determination of Trade Policy", in K. Anderson and R. Blackhurst (eds.) The Greening of World Trade Issues, HarvesterWheatsheaf, HemelHempstead, 195-220.

Hillman, A. and H. Ursprung (1994) "Greens, Supergreens and International Trade Policy: Environmental Concerns and Protectionism", in C. Carraro (ed.) Trade, Innovation, Environment, Kluwer, Dordrecht, 75-108.

Hoel, M. (1997) "Environmental Policy with Endogenous Plant Locations", Scandinavian Journal of Economics, 99(2), 241-259.

Johal, S. and A. Ulph (1998) “Tying Governments' Hands: Why Harmonisation of Environmental Policies May Be Desirable", Southampton Discussion Paper in Economics and Econometrics 9802. 
Kanbur, R., M. Keen and S. van Wijnbergen (1995) "Industrial Competitiveness, Environmental Regulation and Direct Foreign Investment", in I. Goldin and A. Winters (eds.) The Economics of Sustainable Development, Paris, OECD, 289-301.

Knogden, G. (1979) "Environment and Industrial Siting", Zeitschrift fur Umweltpolitik

Leebron, D. (1996) "Lying Down with Procrustes: an Analysis of Harmonisation Claims", in J. Bhagwati and R. Hudec (eds.) Ch. 2.

Levinson, A. (1996a) "Environmental Regulations and Industry Location: International and Domestic Evidence", in J. Bhagwati and R. Hudec (eds.) Ch. 11.

Levinson, A. (1996b) “Environmental Regulations and Manufacturers' Location Choices: Evidence from the Census of Manufactures", Journal of Public Economics, 62, 5 - 29.

McConnell, V. and R. Schwab (1990) "The Impact of Environmental regulation on Industry Location Decisions: The Motor Vehicle Industry", Land Economics, 66, 67 - 81 .

Mani, M., S. Pargal and M. Huq (1997) "Is There an Environmental "Race to the Bottom"? Evidence on the Role of Environmental Regulation in Plant Location Decisions in India" mimeo, World Bank, Washington.

Markusen, J. (1996) "Location Choice and Environmental Quality and Policy" in J. van der Bergh (Ed.) The Handbook of Environmental and Resource Economics, Edward Elgar, Cheltenham, UK, (forthcoming).

Markusen, J., Morey, E., Olewiler, N. (1993) "Environmental Policy when Market Structure and Plant Location are Endogenous", Journal of Environmental Economics and Management 24, 69-86.

Markusen, J., Morey, E., Olewiler, N. (1995) "Noncooperative Equilibria in Regional Environmental Policies when Plant Locations are Endogenous", Journal of Public Economics 56, 55-77.

Motta, M. and J-F. Thisse (1994) "Does Environmental Dumping Lead to Delocation?", European Economic Review, 38, 563-576.

Rauscher, M. (1995) "Environmental Policy and International Capital Allocation", University of Kiel Working Paper.

Rauscher, M. (1997) International Trade, Factor Movements and the Environment, Clarendon Press, Oxford. 
Tobey, J. (1990) “The Impact of Domestic Environmental Policies on Patterns of World Trade: an Empirical Test”, Kyklos, 43, 191-209.

Ulph, A. (1994) “Environmental Policy, Plant Location and Government Protection" in C. Carraro (ed.) Trade, Innovation, Environment, Kluwer, Rotterdam, 123 $-163$.

Ulph, A. (1997a) "International Trade and the Environment: A Survey of Recent Economic Analysis", in H. Folmer and T. Tietenberg (eds.) The International Yearbook of Environmental and Resource Economics 1997/8, Edward Elgar, Cheltenham, 205-242.

Ulph, A. (1997b) "Harmonisation, Minimum Standards and Optimal International Environmental Policy under Asymmetric Information", Discussion Paper in Economics and Econometrics No. 9701, University of Southampton.

Ulph, A. (1998) "Political Institutions and the Design of Environmental Policy in a Federal System with Asymmetric Information", European Economic Review 42, 583-592.

Ulph, A.. and. L. Valentini (1997) "Plant Location and Strategic Environmental Policy with Inter-sectoral Linkages", Resource and Energy Economics 19, 363-383.

Ulph, A. and L. Valentini (1998) "Is Environmental Dumping Greatet When Firms Are Footloose?" mimeo, University of Southampton.

Ulph, D., (1995) "Globalisation and Environmental Dumping: Firm Location and Environmental Policy", Paper presented to Workshop on Environmental Capital Flight, Wageningen University.

van Beers, C. and J. van den Bergh (1997) "An Empirical Multi-Country Analysis of Environmental Policy on Foreign Trade", Kyklos, 50, 29 - 46.

Venables, A. (1994) "Economic Policy and the Manufacturing Base - Hysteresis in Location" Paper Presented to CEPR Workshop on Environmental Policy, International Agreements and International Trade, London.

Wilson, J. (1996) "Capital Mobility and Environmental Standards: Is There a Theoretical Basis for a Race to the Bottom?", in J. Bhagwati and R. Hudec (eds.) Ch. 10. 


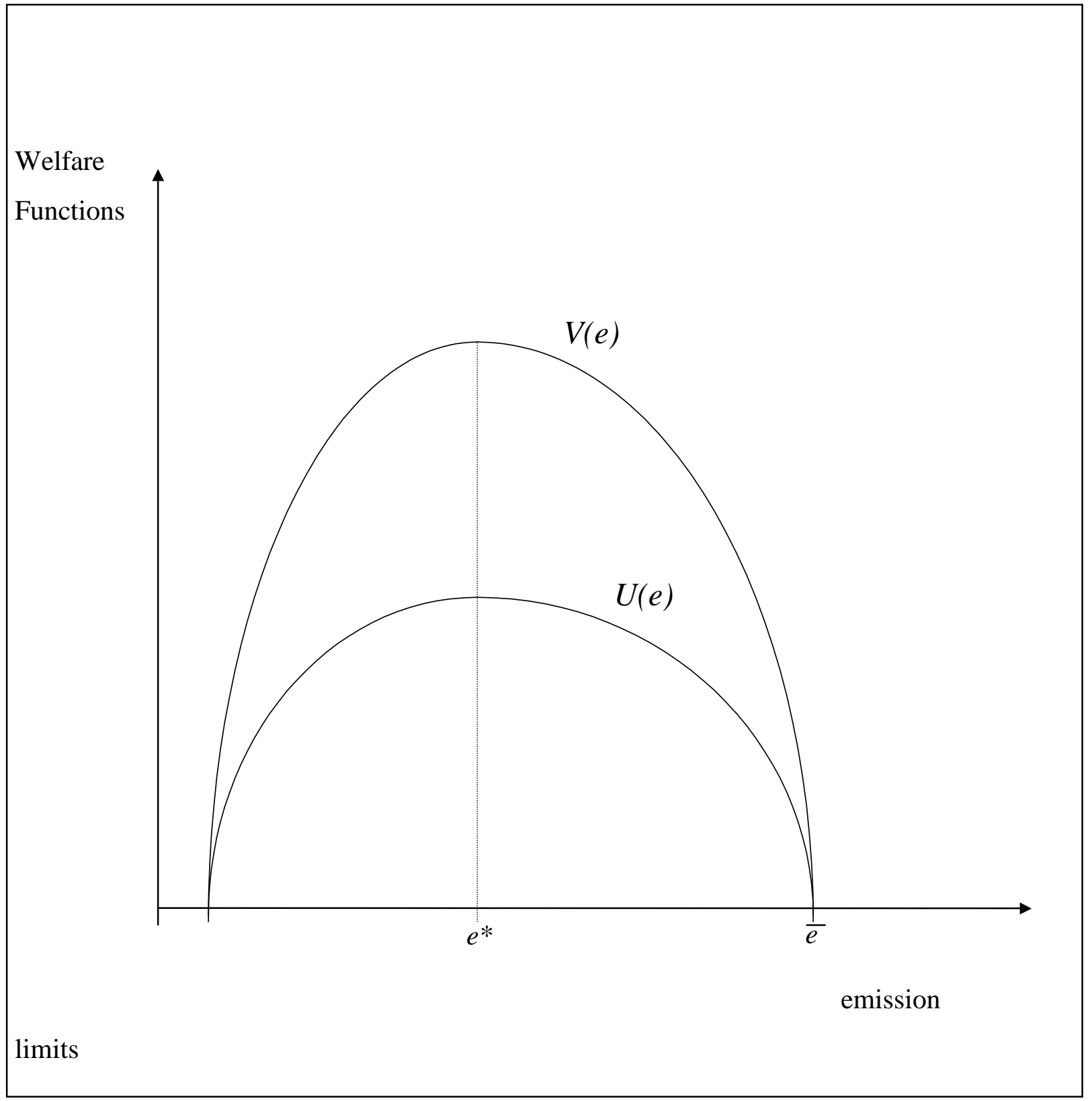

Fig. 1 


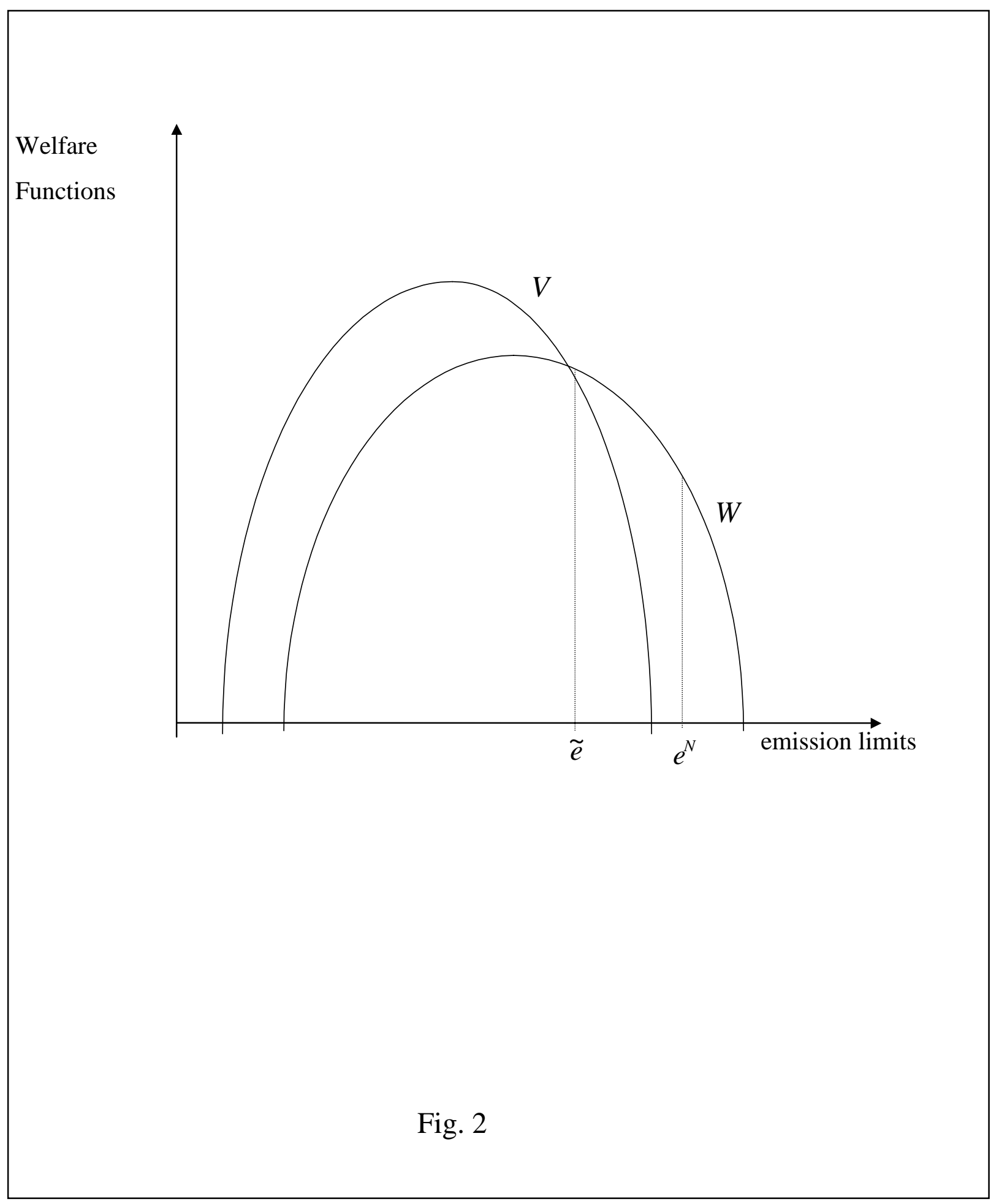


Abatement Falls on Marginal Costs

Fig. 3 
Number of Plants in

Country 1

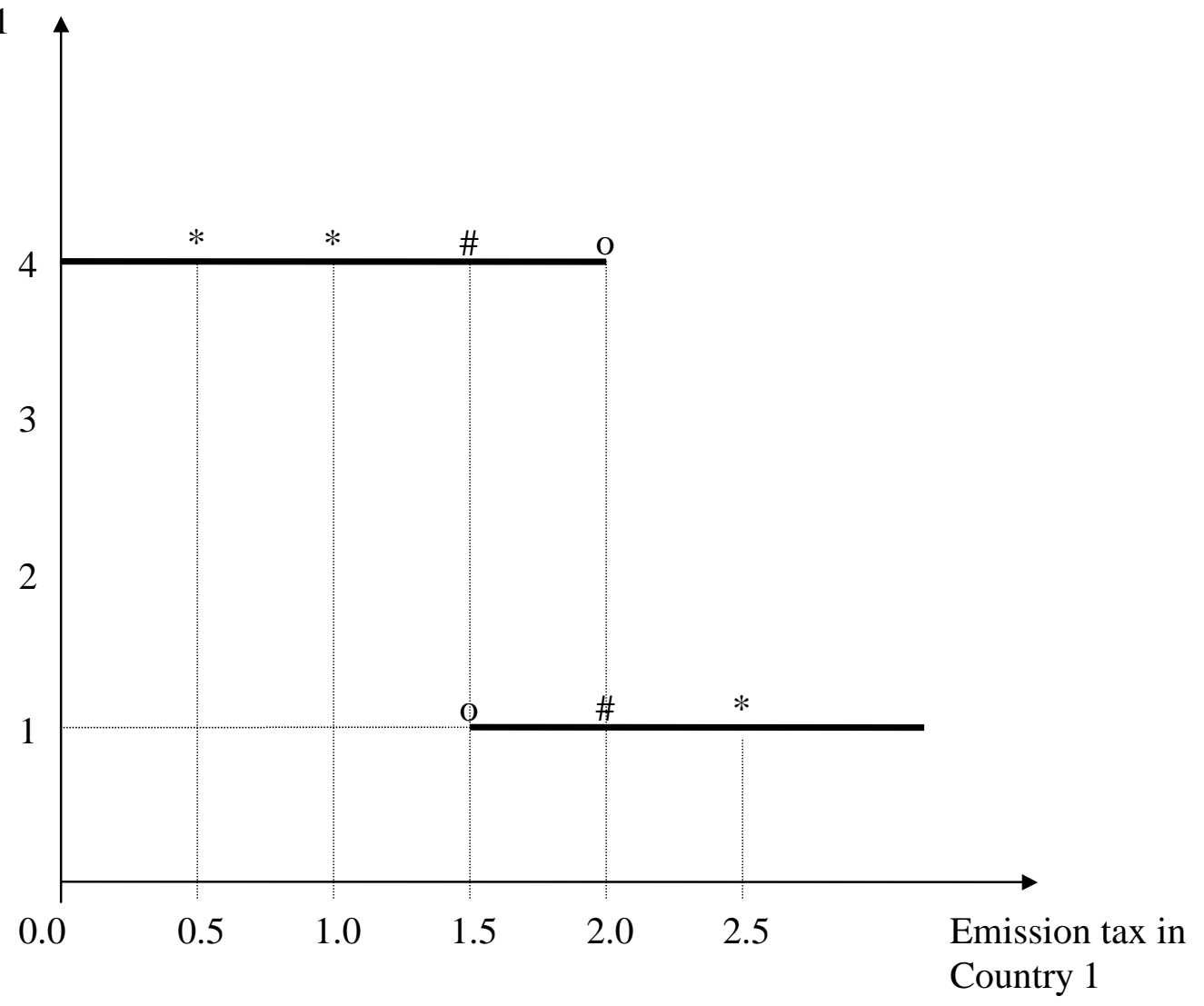

Fig. 4 


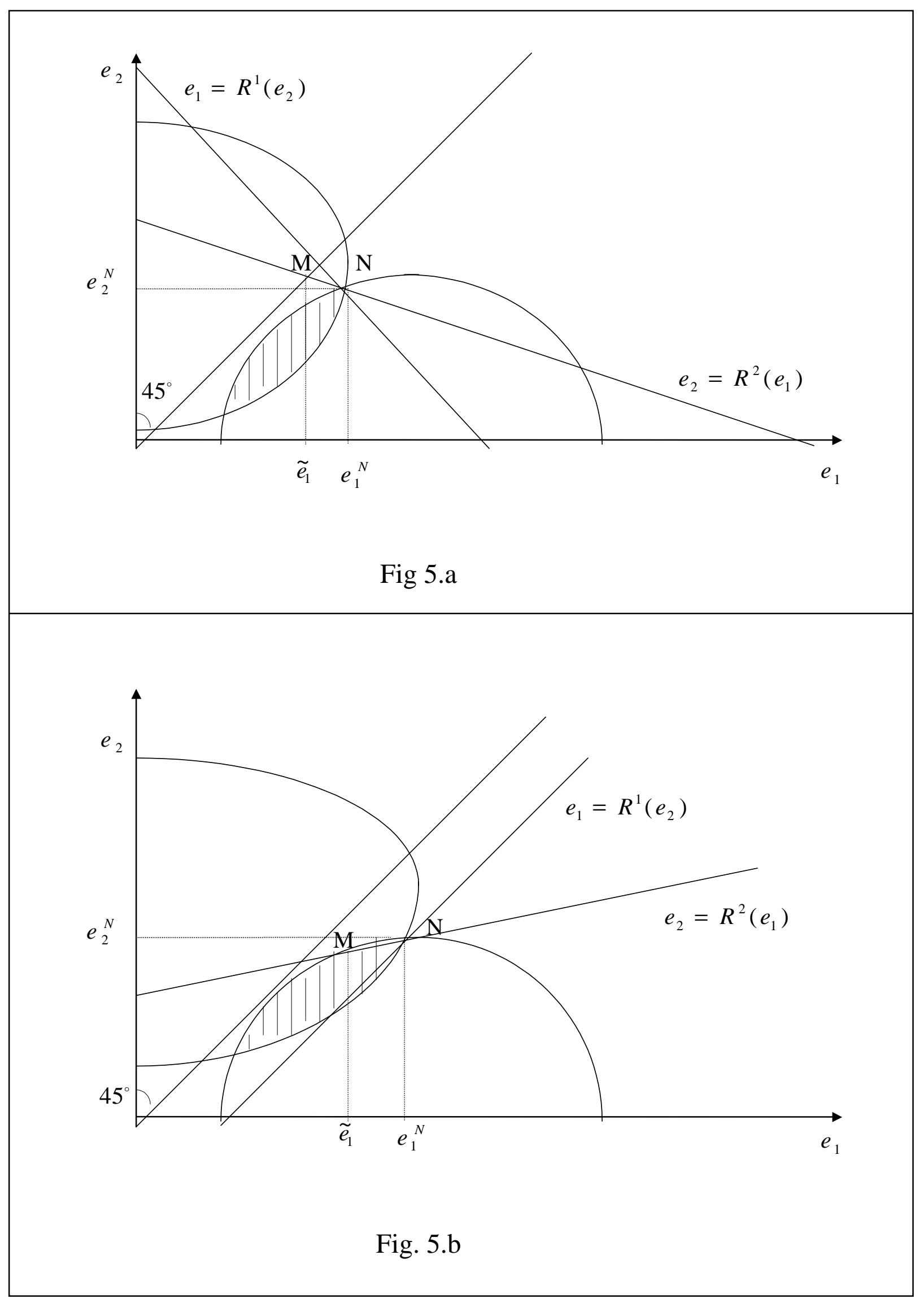




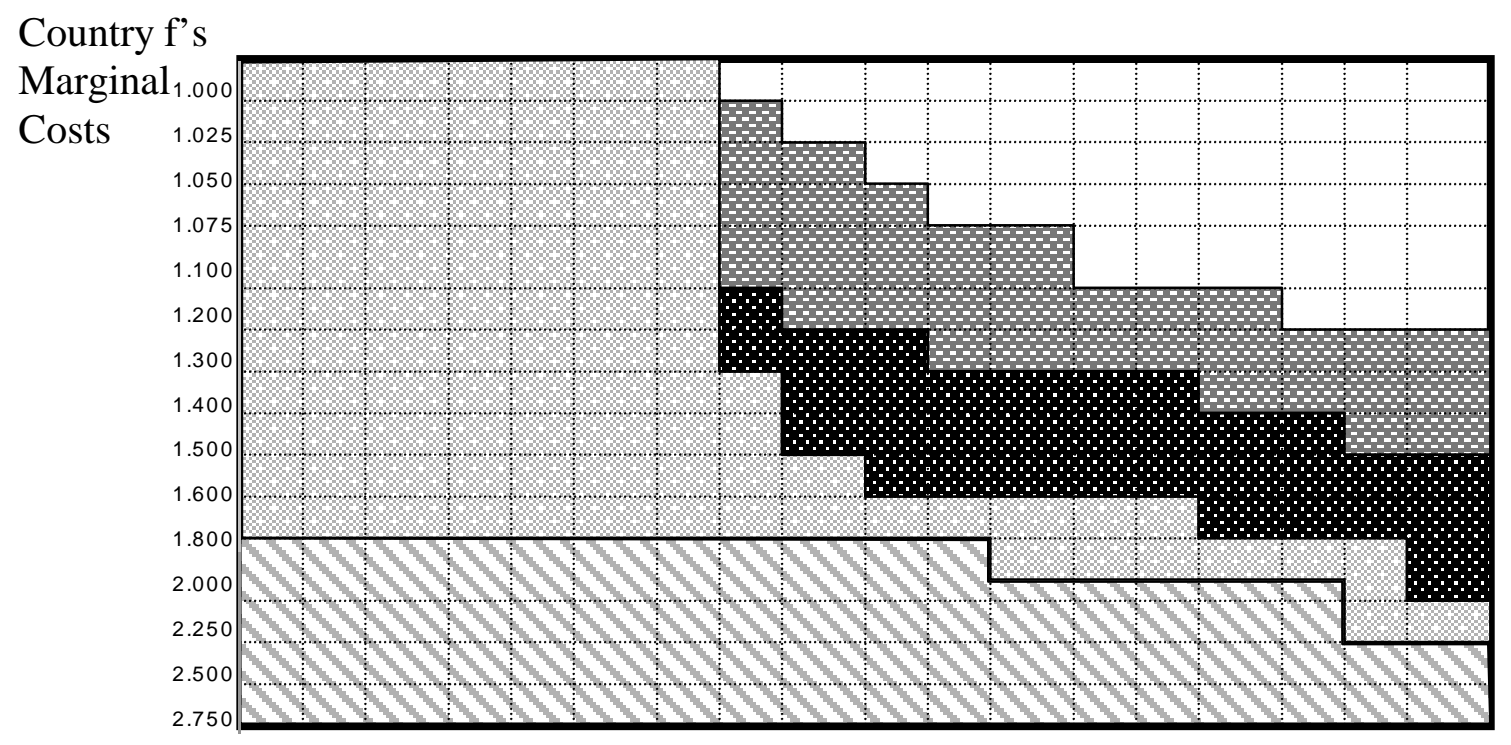

$\begin{array}{llllllllllllllllll}0.01 & 0.02 & 0.03 & 0.04 & 0.05 & 0.06 & 0.08 & 0.10 & 0.12 & 0.14 & 0.16 & 0.18 & 0.20 & 0.24 & 0.28 & 0.32 & 0.36 & 0.40\end{array}$

Transport Costs As A Proportion Of Marginal Production Costs

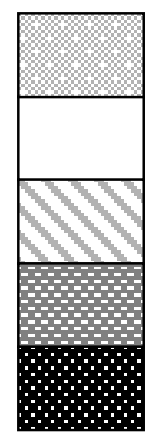

Type $h$ and $f$ firms

Type $\mathrm{m}$ firms

Type $\mathrm{h}$ firms

Type $\mathrm{h}$ and $\mathrm{m}$ firms

Type $\mathrm{h}, \mathrm{m}$ and $\mathrm{f}$ firms

Fig. 3 Abatement Falls on Marginal Costs 